\title{
Creating Value for the Consumer Through Marketing Communication Tools
}

\section{- Viktorija Kovanoviene, Giedrius Romeike, Wjatscheslav Baumung}

\begin{abstract}
The situation in the markets is changing rapidly and competition in the business sector is increasing rapidly. As a result, corporate marketing decisions are based on creating greater value for the consumer, which creates competitiveness and provides an advantage in competing for future customer loyalty. The purpose of this study is to determine whether there is a link between marketing communication tools and consumer perceived value in pursuit of consumer loyalty. Qualitative (observational research) and quantitative (a questionnaire survey) research methods were used to investigate the problem empirically. The observational research elucidated the value provided to the consumer by the research objects through marketing communication tools, supplementing the key questions for the quantitative study. Correlation and regression analysis were used in the study, with the results showing a statistically significant relationship between marketing communication tools and consumer perceived value in terms of user loyalty. It has also been determined that the greatest and strongest relationship in consumer value creation through marketing communication tools is the appropriate, mutually coordinated and complementary use of a package of marketing communication tools to achieve synergies that create the preconditions for increasing consumer loyalty in a competitive market.
\end{abstract}

Keywords: creating consumer value, communicating consumer value, marketing communication tools, consumer perceived value, competitiveness, retail sector

JEL Classification: D46, L81, M31, M39

Received: August, 2020

1st Revision: November, 2021

Accepted: December, 2021

\section{INTRODUCTION}

The competitiveness of an organization ensures its long-term success in the business world. An organization's competitive advantage contributes to the creation and distribution of value to the consumer. Therefore, an organization's marketing activities should be directed at creating value for the consumer, as the basis of marketing activities is to create links between the organization, the user, and all others involved in that development process (Sánchez-Gutiérrez et al., 2019). The more an organization delves into the needs of consumers, the more competitive advantage it will gain (Wu \& Li, 2017). In the scientific literature, successful competition entails the creation 
of value for the consumer that cannot be offered by competitors (Keller, 2013; Malik et al., 2013). In the marketing literature, it is often mentioned that the proper use of marketing communication tools is becoming a modern goal of every organization (Wu \& Li, 2017). It is believed that the consumer is incentivized by an organization that meet his/her needs which are met by marketing communication tools establishing consumer confidence, dedication and satisfaction, all of which foster consumer loyalty in the product, service or brand (Simova, 2009; Hassan, 2012; Keller, 2013; Strydom et al., 2015; Zhang et al., 2016; Wu \& Li, 2017; Sánchez-Gutiérrez et al., 2019).

Despite the abundance of research on value creation for the consumer (Smith \& Colgate, 2014; Zhang et al., 2016; Kotler \& Keller, 2020; Pavlovaite \& Griesiene, 2019), new studies on the use of innovative marketing communication tools related to value creation for the consumer remain extremely relevant. Due to a poor choice of marketing communication tools, the resulting ineffective communication can lead to the consumer remaining uninformed about the organization's product or service, and therefore continuing to make purchases from competitors. And although various marketing communication tools (Išoraite, 2013; Kotler \& Keller, 2020) and their impact on the consumer (Baer, 2013; Shamout, 2016; Blakeman, 2018) have been analyzed quite extensively in the scientific literature, a more in-depth scientific analysis of value creation for the consumer through marketing communication tools will foster understanding as to what motivates the consumer to become loyal to the organization.

Thus, an organization's ability to create and deliver value to the consumer becomes an important aspect of the strategic marketing planning process as well as the formation of a competitive advantage implemented through the consumer perceived value, development and transfer (Baker, 2010). In order to gain a competitive advantage in the future, it is important to understand and adapt to consumers and their needs when planning strategic marketing, and this is properly communicated through marketing communication tools (Dubois et al., 2012; Blakeman, 2018).

Therefore, the purpose of the study is to determine whether there is a link between marketing communication tools and consumer perceived value in the ultimate pursuit of consumer loyalty. This study was conducted to elucidate the influence of marketing communication tools on user loyalty in terms of marketing tools to communicate user-desired values. The marketing communication tools used by the three largest retail chains in Lithuania were investigated as well as the values they communicate to the consumer along with the opinions of visitors to those retail chains. Qualitative observation and quantitative questionnaire survey methods were used in the research part.

Despite the increasing amount of literature on value creation in the world, both a theoretical and empirical understanding that reflect the complexity and dynamism of the delivery of value to customers through marketing communication tools are still a relevant and timely problem. This study contributes to this research gap, presenting the characteristics of customer value that contribute to creating value for consumer through marketing communication tools, creating real preconditions for increasing consumer loyalty and ensuring the future competitiveness of the organization.

The paper consists of a literature background as well as descriptions of the research objective, the methodology, data and results along with a discussion and presentation of conclusions. 


\section{LITERATURE BACKGROUND}

Attracting consumers in a highly competitive environment requires a great deal of effort, as the wants and needs of the consumer tend to change frequently. In today's world, consumer behavior is always changing. Consumers are much more involved in the activities of organizations, with even the role of consumers itself evolving from an passive role to an active one. The consumer becomes well informed, determining what he/she wants in terms of a high value-added product well before a purchase is made. These phenomena occur because the modern consumer is generally much better informed, e.g. through the active use of information communication technologies, and therefore, distance and social barriers have largely disappeared (Prahalad \& Ramaswamy, 2004; Hsiao et al., 2011; Lindgreen et al., 2012; Piercy, 2016). The success of an organization comes to depend on how it is able to create unique perceived value for the consumer and how it is able to communicate this value through marketing communication tools. As a result, modern marketing relies on a systemic approach which can be shifted to meet consumer needs. Value creation for the consumer is becoming more important both due to both competition between organizations as well as the expanded market power of consumers and their increasingly welldefined demands (Gronroos \& Ravald, 2011; Pynnonen et al., 2011; Kumar \& Raju, 2013; Abtin \& Pouramiri, 2016; Zhang et al., 2016; Gan \& Wang, 2017; Kotler \& Keller, 2020).

According to researchers, it is necessary to adopt a value-based approach to marketing in which value propositions are created during the value creation process for the target market (Baker, 2010; Piercy, 2016; Solomon et al., 2017). The result of creating value for the consumer is the establishment of a value proposition and its communication, defining a product or service which consumers want to buy, following which the organization can meet this perceived need (Baker 2010). This process is reflected in the exchange between the organization and the user, enhancing reciprocity of communication. The construction of a successful value proposition depends on the ability to define value with a proper view of user needs, and on the relative attractiveness of different consumer segments. The organization can then work to create this value and ultimately deliver it by communicating it to the consumer (Baker, 2010).

As a result, value creation for the consumer is relevant and often examined through the components of perceived consumer value, which may vary depending on the subject and selection of subjects (Simova, 2009; Hassan, 2012; Shanker, 2012; Strydom, 2015; Zhang et al., 2016; Wu \& Li, 2017). Consumer perceived value has been examined in the scientific literature as a component of value creation for the consumer, as the final assessment essentially means the perceived benefit the consumer receives from a good or service (Simova, 2009; Candan et al., 2013; Kumar \& Reinartz, 2016; Gan \& Wang, 2017). According to many authors, in order to please the consumer and to understand his needs it is necessary to assess the value of the offered product or service by providing a systematic interpretation of the components of perceived value (Gatautis et al., 2016):

- Functional value is the benefit that is most influenced by price. The consumer feels (longterm or short-term) satisfaction that he has purchased a product or service at a good price, and thus he has reduced his costs. According to the analyzed scientific literature, this value 
most often includes the price, quality, and range of assortment of the product of service (Simova, 2009; Hsiao et al., 2011; Hassan, 2012; Candan et al., 2013; Strydom, 2015; Wagner \& Benoit, 2015; El-Aldy \& Eid, 2016; Yoong et al., 2017).

- Social value is a certain benefit to the consumer connected to the satisfaction of using a product or using a service in comparison or contrast to other people in the same social group. According to the scientific literature, this value most often entails belonging to a social group, communality, etc. (Zhang et al., 2016; Wu \& Li, 2017; Yoong et al., 2017; Itani et al., 2019).

- Emotional value is the perceived benefit of certain feelings induced in the consumer. It is these feelings that arouse the consumer's desire to buy a product or take advantage of a service. According to the scientific literature, this value most often includes store environment, staff competence, a positive shopping experience, positive feedback from other people, seller reputation, etc. (Simova, 2009; Hsiao et al., 2011; Hassan, 2012; Shanker, 2012; Candan et al., 2013; Strydom et al., 2015; Wagner \& Benoit, 2015; El-Aldy \& Eid, 2016; Zhang et al., 2016; Yoong et al., 2017).

- Epistemic value is the useful properties of a product that help create innovation or satisfy a desire for knowledge. According to the analyzed scientific literature, this value most often includes distance to the seller, shopping convenience, and the technologies used by the seller (Hsiao et al., 2011; Shanker, 2012; Strydom et al., 2015; El-Aldy \& Eid, 2016; Wu \& Li, 2017; Yoong et al., 2017).

- Conditional value is the characteristics that a product acquires as a result of special or social conditions that highlight its functional or social usefulness. According to the scientific literature, this value most often includes time, situation, shopping experience (Hsiao et al., 2011; Candan et al., 2013; Strydom et al., 2015; Wagner \& Benoit, 2015; El-Aldy \& Eid, 2016; Yoong et al., 2017).

Arguably, it is most effective if the organization is able to meet all the values to the consumer. However, as research shows, different businesses are impressed by different types of values, so it is important to understand and focus on the kind of value creation that is appropriate for that particular business (Gatautis et al., 2016).

For a user to understand the value an organization offers, it must be communicated. The stage of communicating value for the consumer in marketing is important and involves a variety of marketing communication actions aimed at convincing the consumer that the organization's offer is unique and appealing (Lindgreen et al., 2012; Ngo \& O’Cass, 2010; Kumar \& Raju, 2013; Kotler \& Keller, 2020).

Marketing communication actions and the means of communication used are directed at the consumer not by chance, their goal is for the consumer to return to buy again and become a loyal consumer (Wu \& Li, 2017; Itani et al., 2019, Marinov \& Marinova, 2019). The effectiveness of the use of marketing communication tools is generally accepted as a financial return that provides an organization with feedback on its marketing activities (Martelo Landroguez et al., 2013; 
Hanssens \& Pauwels, 2016; Kotler \& Keller, 2020). Therefore, it is recommended to implement the communication policy of each organization using various marketing communication tools. This article draws on the most common means of integrated marketing communication in the marketing literature: advertising, sales promotion, personal sales, public relations, direct marketing (Kotler \& Keller, 2020).

As for the marketing communication tools, they are often mentioned by other authors as being necessary to create value for the consumer, but are not considered to be as a contribution to creating value for the consumer. Many authors (Simova, 2009; Hassan, 2012; Strydom, 2015; Wagner \& Benoit, 2015; Zhang et al. 2016; Wu \& Li, 2017; Itani et al., 2019) delve more deeply into the aspects of value to the consumer or perceived value to the consumer, which may result in consumer satisfaction, consumer loyalty, or a purchase decision.

For many companies, the consumers' loyalty represents a significant competitive advantage (Nezakati et al., 2013), which has a significant impact on the commercial success of the organization. The researches carried out so far demonstrated that the consumers' loyalty can maximize an organization profits because loyal customers are willing to purchase more frequently, spend money on trying new products or services, recommend products and services to others, and give companies sincere suggestions (Khan, 2013).

The essence of marketing communication tools is to help build a relationship between the consumer and the brand or company, so it can be considered to be a key tool for shaping consumer loyalty (Yang \& Lee, 2016). Even a good product at a reasonable price will fail if its properties and benefits are not communicated (Singh \& Pattanayak, 2014). Therefore, the proper use of marketing communication tools is also important for the overall success of the organization, as it helps the organization to build customer loyalty, ensures stability, lower costs and competitive advantage (Blakeman, 2018).

Summarizing the analyzed scientific literature, it was observed that all the authors agree that value creation for today's consumer is essential for an organization to remain competitive in the marketplace. And by defining the link between value creation for the consumer through marketing communications, it can be said that an organization will be able to compete in the market when it has customers loyal to it, who will understand the values offered to them, which will be communicated through marketing communication tools.

\section{RESEARCH OBJECTIVE, METHODOLOGY AND DATA}

The purpose of the study is to verify whether there is a link between marketing communication tools and consumer perceived value in pursuit of consumer loyalty. Therefore, the proposed theoretical model (Figure 1) is a holistic model based on the correlation between factors that can have a positive impact on consumer loyalty. 


\begin{tabular}{|l|l|l|}
\hline $\begin{array}{c}\text { Marketing } \\
\text { Communication } \\
\text { Tools }\end{array}$ \\
\hline Advertising
\end{tabular}

Fig. 1 - Theoretical model of creating value for consumer through marketing communication tools. Source: own research

According to the proposed model, value creation for the consumer is carried out by a retail services provider through marketing communication tools that communicate values to the consumer. The result of the process is gained or increased consumer loyalty.

An analysis of the scientific literature has shown that marketing communication tools must be used to convey value to the consumer and in the hope that he will understand that value properly. As a result, many studies examine consumer perceived value and its components (Simova, 2009; Smith \& Colgate, 2014; Kotler \& Keller, 2020). By knowing what components of consumer perceived value need to be emphasized, each organization will gain consumer attention through marketing communication tools, and will stand out and compete in the marketplace (Hassan, 2012; Smith \& Colgate, 2014; Strydom et al., 2015; Zhang et al., 2016). Therefore, the hypothesis $\mathrm{H} 1$ is raised: There is a direct relationship between the effectiveness of the marketing communication tools used and the increase in the consumer perceived value (volume).

As the analyzed research (Simova, 2009; Hassan, 2012; Strydom et al., 2015; Zhang et al., 2016; Wu \& Li, 2017; Itani et al., 2019) has shown, the contribution of individual marketing communication tools to the creation of value for the consumer is not highly researched subject, therefore, the following hypotheses were further tested:

Hypothesis H1a: There is a direct link between the effectiveness of the advertising tools used and the increase in the consumer perceived value (volume).

Hypothesis H1b: There is a direct link between the effectiveness of the sales promotion measures used and the increase in the consumer perceived value (volume).

Hypothesis H1c: There is a direct link between the effectiveness of the personal selling tools used and the increase in the consumer perceived value (volume).

Hypothesis H1d: There is a direct link between the effectiveness of the public relations tools used and the increase in the consumer perceived value (volume).

Hypothesis H1e: There is a direct link between the effectiveness of the direct marketing tools used and the increase in the consumer perceived value (volume). 
Many studies investigating value creation for the consumer have shown that value created for the consumer has a positive effect on consumer loyalty (Simova, 2009; Gronroos \& Ravald, 2011; Pynnonen et al., 2011; Hassan, 2012; Strydom et al., 2015; Zhang et al., 2016). Consumer loyalty depends on the quality and characteristics of the goods or services and the totality of the data, which is directly related to the ability to meet the expressed or implied needs of consumers (Smith \& Colgate, 2014; Zhang et al., 2016; Sánchez-Gutiérrez et al., 2019; Kotler \& Keller, 2020). Therefore, the hypothesis H2 is raised: Strengthening consumer perceived value has an impact on consumer loyalty growth.

Any organization that has already identified the needs of its users and provides them with products that meet those needs cannot, of course, stop at that process. It must receive feedback from its users and continually improve both its products or services and the broadcasting of those products or services through marketing communications tools (Malik et al., 2013; Shamout, 2016). Therefore, the hypothesis H3 is raised: Strengthening consumer loyalty influences the effectiveness of the marketing communication tools used.

\section{Research methods and data}

Qualitative and quantitative research methods were used to investigate the problem of empirical research.

Qualitative research was performed by choosing the observation method. The observation object- retail chain industry. Purpose of the observational study - to distinguish the values to the consumer that are communicated by retail chains through marketing communication tools. Qualitative research methods for primary impartial data collection: standardized observation; biotic observation; observation without the presence of an observer; observation field. The data of the qualitative research were processed by applying the method of qualitative content analysis. The information gathered was used in a quantitative study to create a survey questionnaire.

Following the recommendations and Best Practices of marketing research for quantitative research, Online Survey method was chosen. A questionnaire was designed from Filtering (1), Introductory (3) and Fundamental (3) questions. The sample size (with the confidence level of 95 percent): 384 respondents. Data analysis was performed using a combination of Microsoft Office Excel and SPSS statistical analysis package, performing correlation analysis and linear regression analysis.

\section{RESULTS AND DISCUSSION}

This section presents the results and discussions of the observation study and questionnaire survey.

\subsection{Observation study results and discussion}

Observation study (qualitative content analysis) was carried out at the beginning of 2020 (Jan.27Mar.5) and took 5 weeks. The observation objects were 3 bigger retail chains with different international experience and which together hold more than 58 percent of Lithuanian retail market share. The biggest challenge related with research was the abundance of data and 
information (in the research period, the retail chains were the biggest advertisers in Lithuania), which required respective resources for data collection and content analysis. The results of the observation study showed that value to the consumer can be created through marketing communication tools. The values communicated to the consumer by retail chains through different marketing communication tools were clarified (see Table 1).

Tab. 1 - Results of the observation research. Source: own research

\begin{tabular}{|c|c|c|c|c|c|c|c|c|c|c|c|c|c|c|c|}
\hline \multirow[b]{3}{*}{$\begin{array}{l}\text { Marketing } \\
\text { communication tools }\end{array}$} & \multicolumn{15}{|c|}{ Consumer perceived value } \\
\hline & \multicolumn{3}{|c|}{ Functional } & \multicolumn{2}{|c|}{ Social } & \multicolumn{4}{|c|}{ Emotional } & \multicolumn{3}{|c|}{ Epistemic } & \multicolumn{3}{|c|}{ Conditional } \\
\hline & 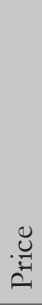 & $\stackrel{\stackrel{\Xi}{\rightrightarrows}}{\stackrel{\Xi}{3}}$ & 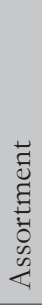 & 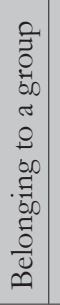 & 㤂 & 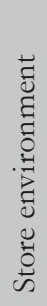 & 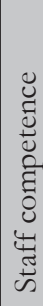 & $\begin{array}{l}0 \\
3 \\
0 \\
0 \\
0 \\
0 \\
0 \\
0 \\
0 \\
0 \\
0 \\
0 \\
3 \\
0\end{array}$ & 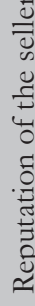 & 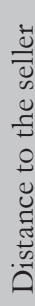 & 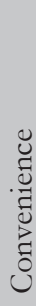 & $\frac{\mathscr{\varrho}}{0}$ & $\underset{\Xi}{\mathscr{F}}$ & 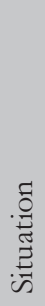 & 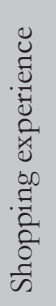 \\
\hline Advertising & $\mathrm{x}$ & $\mathrm{x}$ & $\mathrm{x}$ & $\mathrm{x}$ & $\mathrm{x}$ & $\mathrm{x}$ & $\mathrm{x}$ & $\mathrm{x}$ & $\mathrm{x}$ & $\mathrm{x}$ & $\mathrm{x}$ & $\mathrm{x}$ & $\mathrm{x}$ & $\mathrm{x}$ & $\mathrm{x}$ \\
\hline Sale promotion & $\mathrm{x}$ & & $\mathrm{x}$ & $\mathrm{x}$ & $\mathrm{x}$ & & & & & & & & & & \\
\hline Personal sale & & & $\mathrm{x}$ & & & & $\mathrm{x}$ & & & & $\mathrm{x}$ & & & & $\mathrm{x}$ \\
\hline Public relations & & & $\mathrm{x}$ & & $\mathrm{x}$ & & $\mathrm{x}$ & & $\mathrm{x}$ & & $\mathrm{x}$ & $\mathrm{x}$ & & & \\
\hline Direct marketing & $\mathrm{x}$ & & $\mathrm{x}$ & & & & & & & & $\mathrm{x}$ & & $\mathrm{x}$ & & \\
\hline
\end{tabular}

By summarizing the results of the observation study (see Table 1), it can be said that retailers most commonly used marketing communication tools to communicate product price, assortment, belonging to a group, communality, staff competence and convenience value. Moreover, the marketing communication tool "advertising," is used to communicate all possible values to the consumer, thus hoping to reach the widest possible audience and to attract loyal consumers, as the analyses of authors from other countries (Europe, Asia, America, Africa) have shown, the elements of value creation for the consumer are similar and often repeated. Similar international research has confirmed that the consumer usually prefers the following values: product price, quality, staff competence, good feedback from other consumers, seller reputation, the right assortment, convenience and a positive shopping experience (Simova, 2009; Hsiao et al., 2011; Hassan, 2012; Shanker, 2012; Candan et al., 2013; Strydom et al., 2015; Wagner \& Benoit, 2015; El-Aldy \& Eid, 2016; Zhang et al., 2016; Wu \& Li, 2017; Yoong et al., 2017; Itani et al., 2019).

These studies have been carried out in different sectors of activity, such as clothing retailing, online shopping, supermarkets, open source business, personal care products, high fashion retailing, mobile applications, microblogging platforms, social commerce, telecommunication industry, restaurants, and confirm that creating value for the consumer is still relevant, and that organizations are paying more and more attention to it when competing with each other.

The observation study suggests that the values highlighted in the study (see Table 1) can be applied to other sectors of activity, but this requires more in-depth research with similar research instruments. A questionnaire was prepared based on the results of the observation study. 


\subsection{Questionnaire survey results and discussion}

The quantitative research data were collected from 398 respondents, visitors of retail chains in Lithuania. The questionnaire survey was conducted at the beginning of 2020 (Feb. 28 - Mar.25). The main predictable challenge of quantitative research was a proper information interpretation in the questionnaire design, which would allow to the respondent to understand correctly the meaning of the question and recognize the analysed marketing communication tools, terms, names used in scientific and business literature. Despite the fears, the survey results showed that respondents (visitors of retail chains) notice and know the marketing communication tools used by retail chains, they also understand what values are communicated to them. They often agree with the claims that the use of marketing communication tools for retail chains is necessary because it potentially promotes consumer loyalty. Therefore, strengthening consumer loyalty by increasing consumer perceived value has implications for the use of marketing communication tools, that is, the more the consumer understands what is being communicated to him, the more likely he is to recognize this as value and, therefore, visits the retail chain. To this end, the correlation coefficients between the variables were calculated: "Marketing communication tools", "Consumer perceived value" and "Consumer loyalty" (see Table 2).

Tab. 2 - Correlation coefficients between variables. Source: own research

\begin{tabular}{|c|c|c|c|c|}
\hline \multicolumn{5}{|c|}{ Spearman's rho Correlations } \\
\hline & & $\begin{array}{l}\text { Marketing } \\
\text { communication } \\
\text { tools }\end{array}$ & $\begin{array}{l}\text { Consumer } \\
\text { perceived } \\
\text { value }\end{array}$ & $\begin{array}{l}\text { Consumer } \\
\text { loyalty }\end{array}$ \\
\hline \multirow[t]{3}{*}{$\begin{array}{l}\text { Marketing } \\
\text { communication tools }\end{array}$} & $\begin{array}{l}\text { Correlation } \\
\text { Coefficient }\end{array}$ & 1.000 & $.803 * *$ & $.750 * *$ \\
\hline & Sig. (2-tailed) & . & .000 & .000 \\
\hline & $\mathrm{N}$ & 398 & 398 & 398 \\
\hline \multirow[t]{3}{*}{$\begin{array}{l}\text { Consumer perceived } \\
\text { value }\end{array}$} & $\begin{array}{l}\text { Correlation } \\
\text { Coefficient }\end{array}$ & $.803 * *$ & 1.000 & $.691 * *$ \\
\hline & Sig. (2-tailed) & .000 & . & .000 \\
\hline & $\mathrm{N}$ & 398 & 398 & 398 \\
\hline \multirow[t]{3}{*}{ Consumer loyalty } & $\begin{array}{l}\text { Correlation } \\
\text { Coefficient }\end{array}$ & $.750 * *$ & $.691 * *$ & 1.000 \\
\hline & Sig. (2-tailed) & .000 & .000 & . \\
\hline & $\mathrm{N}$ & 398 & 398 & 398 \\
\hline
\end{tabular}

**. Correlation is significant at the 0.01 level (2-tailed).

The relationship between the variables is statistically significant, because the p-value (Sig.) of the criteria in this category is lower than the set significance level (0.01). The relationship between the variables is positive, all coefficients with a plus sign. There is a strong link between the variables "Marketing communication tools" and "Consumer perceived value" ( $\mathrm{r}-0.803)$, also between the variables "Consumer loyalty" and "Marketing communication tools" ( $r-0.750)$. There is a 
moderaly strong link between the variables "Consumer perceived value" and "Consumer loyalty" ( $r-0.691)$. The problem of multicollinearity should not arise. All correlations are statistically significant (all p values are $0.000<0.05$ ).

Consequently, creating value for the consumer through marketing communication tools is very important if an organization wants to compete. However, in order to achieve consumer loyalty, it is necessary to explore additional factors that would encourage this.

The correlation between different marketing communication tools and "Consumer perceived value" is presented in Table 3 .

Tab. 3 - The correlation between different marketing communication tools and "Consumer perceived value." Source: own research

\begin{tabular}{|l|l|l|l|l|l|l|}
\hline \multicolumn{2}{|l|}{ Spearman's rho } & Advertising & $\begin{array}{l}\text { Sales } \\
\text { promotion }\end{array}$ & $\begin{array}{l}\text { Personal } \\
\text { sale }\end{array}$ & $\begin{array}{l}\text { Public } \\
\text { relations }\end{array}$ & $\begin{array}{l}\text { Direct } \\
\text { marketing }\end{array}$ \\
\hline $\begin{array}{l}\text { Consumer } \\
\text { perceived } \\
\text { value }\end{array}$ & $\begin{array}{l}\text { Correlation } \\
\text { Coefficient }\end{array}$ & $.765^{* *}$ & $.704^{* *}$ & $.522^{* *}$ & $.695^{* *}$ & $.677^{* *}$ \\
\cline { 2 - 7 } & Sig. (2-tailed) & 0.000 & 0.000 & 0.000 & 0.000 & 0.000 \\
\cline { 2 - 7 } & $\mathrm{N}$ & 398 & 398 & 398 & 398 & 398 \\
\hline
\end{tabular}

**. Correlation is significant at the 0.01 level (2-tailed).

There is a strong link between the variables "Advertising" and "Consumer perceived value" $(\mathrm{r}-0.765)$, also between the variables "Sales promotion" and "Consumer perceived value" ( $\mathrm{r}-$ 0.704). A moderately strong link exists between the variables "Public relations" and "Consumer perceived value" ( $\mathrm{r}-0.695)$. There is a moderate link between the variables "Direct marketing" and "Consumer perceived value" ( $\mathrm{r}-0.677)$, as well as between the variables "Personal sale" and "Consumer perceived value" (0.522). Interestingly, the relationship between the variables "Marketing communication tools" and "Perceived user value" is strong, and the relationship between different marketing communication tools (advertising, sales promotion, personal sale, public relations, direct marketing) and "Consumer Perceived Value" ranges from medium to strong. This is confirmed by the information found in the observation study that retailers use advertising tools extensively and communicate the values most often, which is why the connection is strongest, with personal sales tools less enforced by the seller or recognizable to the consumer, resulting in a medium interconnection.

A simple linear regression analysis was then performed, and the hypotheses raised in the work tested (see Table 4).

Tab. 4 - Regression analysis data. Source: own research

\begin{tabular}{|l|l|l|l|l|l|l|}
\hline & Dependent variable & Independent variable & R2 & ANOVA p & Beta & VIF \\
\hline H1 & $\begin{array}{l}\text { Consumer perceived } \\
\text { value }\end{array}$ & $\begin{array}{l}\text { Marketing } \\
\text { communication tools }\end{array}$ & 0.623 & 0.000 & 0.789 & 1 \\
\hline
\end{tabular}




\begin{tabular}{|l|l|l|l|l|l|l|}
\hline H1a & $\begin{array}{l}\text { Consumer perceived } \\
\text { value }\end{array}$ & Advertising & 0.558 & 0.000 & 0.747 & 1 \\
\hline H1b & $\begin{array}{l}\text { Consumer perceived } \\
\text { value }\end{array}$ & Sale promotion & 0.460 & 0.000 & 0.678 & 1 \\
\hline H1c & $\begin{array}{l}\text { Consumer perceived } \\
\text { value }\end{array}$ & Personal sale & 0.280 & 0.000 & 0.529 & 1 \\
\hline H1d & $\begin{array}{l}\text { Consumer perceived } \\
\text { value }\end{array}$ & Public relation & 0.475 & 0.000 & 0.690 & 1 \\
\hline H1e & $\begin{array}{l}\text { Consumer perceived } \\
\text { value }\end{array}$ & Direct marketing & 0.440 & 0.000 & 0.663 & 1 \\
\hline H2 & $\begin{array}{l}\text { Consumer loyalty } \\
\text { H3 }\end{array}$ & $\begin{array}{l}\text { Consumer perceived } \\
\text { value }\end{array}$ & 0.437 & 0.000 & 0.661 & 1 \\
\hline
\end{tabular}

Table 4 shows that all coefficients of determination are higher than 0.20 . This means that the coefficients of determination remain large enough that the linear regression model cannot yet be ruled out as inappropriate.

All ANOVA criterion p (Sig.) values are less than 0.05. It is concluded that the regressor in the model depends on the dependent variable, thus there is a linear dependence between the variables. This means that the effective use of marketing communication tools properly was shown to communicate value to the consumer. As a result, the consumer perceived value (volume) increases. Also, in the study case, by strengthening the consumer's perception of the communicated values to the consumer, consumer loyalty to the organization increases. Consequently, strengthening consumer loyalty by communicating values he / she understands increases the effectiveness of the marketing communication tools used.

To understand which regressor is more influential in the model, we looked at the standardized coefficient Beta, through which we can see that the least influential regressor is "Personal Sales" (Beta - 0.529), and the most influential regressor "Marketing Communication Tools" (Beta-0.789). Also, all regressors are statistically significant since the Student $\mathrm{p}$-values for each coefficient are $\mathrm{p}<0.05$, thus they show an independent influence on the level of the dependent variable.

There is no multicollinearity problem, since for all regressors, VIF $=1$.

In summarizing the statistical assertion of hypotheses it can be stated that all the hypotheses were confirmed, i.e. all relationships identified during the theoretical analysis are statistically significant and there is a direct and positive influence of the variables on each other.

In summarizing the results of the questionnaire survey it can be stated that creating value for the consumer through marketing communications was shown to be significant. A correlation analysis confirmed the theoretical relationships of the variables, which are significant and quite strong. A regression analysis investigated the causality of the relationships of the variables, showing a direct, positive, statistically significant, and strong influence among the variables studied. Thus, 
according to the developed theoretical research model of creating value for consumers through marketing communication tools, a relationship was shown between marketing communication tools and consumer perceived value in terms of achieving consumer loyalty. It is important to mention that the obtained results reflect the research case of large retail chains in Lithuania only in an examination of the marketing communication tools used by retail chains along with the values they transmit to the consumer, although the effectiveness of the same measures has not been further investigated.

Comparing our study with that of other authors is difficult because identical or even similar research instruments have not been used by other authors. It should also be emphasized that the examined retail chains are the most popular in Lithuania (as shown by the results of a questionnaire survey) and each chain has a different, albeit significant, international background:

- Maxima LT, UAB, the company that manages MAXIMA retail chain, is the largest Lithuanian capital company, as well as one of the largest taxpayers and the largest employer in the country. The company owns more than 1,200 grocery retail stores in the Baltic States (Maxima), Poland (Stokrotka), and Bulgaria (T-market)

- LIDL is a German-origin international discount groceries supermarket chain that operates in 32 countries worldwide, with over 10,800 stores in 29 countries across Europe, the United States and Hong Kong

- the IKI chain of grocery stores 1992 was established in Lithuania by Belgium founders; since 2008 it has been owned operated by the REWE Group, a leading retail chain operator and the foremost trade and tourism group within Germany and in Europe. The REWE Group currently operates in 22 European countries and owns a number of local and international grocery chains such as PENNY, BILLA, Merkur, and AGM.

After an examination of these companies' websites dedicated to the retail business in different countries, it can be stated that the means of communication used by these chains demonstrates features of unification, with similar marketing communication tools used across their international regions. This therefore allows us to assume that our research results, interpretation and suggestions could be used for retail industry marketing communication planning internationally. A specific application in a particular country or region, would of course require more in-depth research.

\section{CONCLUSION}

Various researchers have suggested directions for further study on creating value for the consumer through marketing communication tools. After reviewing the works of other authors on the research topic, it was found out that creating value for the consumer can be done through marketing communication, communicating values to the consumer (such as price of the product, quality of the product, assortment, belonging to a group, communality, store environment, staff competence, positive shopping experience, positive feedback from other people, seller reputation, distance to the seller, convenience of shopping, technologies, time, situation, shopping experience) in anticipation of the relevant consumer behavior (for example, consumer 
loyalty). Notwithstanding the previous research, the constant fluctuations of the market as well as consumer trends continue to make the influence of marketing communication tools on creating value for the consumer a relevant topic that needs to be explored in more detail.

A theoretical model of value creation for the consumer through marketing communication tools was proposed. This holistic model has been tested in practice through empirical research which established a relationship between marketing communication tools and consumer perceived value in order to achieve consumer loyalty. Creating value for the consumer through marketing communications has been proved to be significant. "Marketing communication tools" were shown to have a direct and positive strong relationship $(r-0.803)$ and a strong positive influence (B - 0.789) on "Consumer perceived value." "Consumer perceived value" has a direct and moderately strong relationship $(\mathrm{r}-0.691)$ and a relatively strong influence $(\mathrm{B}$ - 0.661) on "Consumer loyalty." "Consumer loyalty" has a direct and strong connection ( $\mathrm{r}$ $0.750)$ and a strong influence $(\mathrm{B}-0.789)$ on "Marketing communication tools." Out of all the marketing communication tools examined, "Advertising" ( $\mathrm{r}-0.765)$ and "Sales promotion" ( $\mathrm{r}-$ 0.704) showed the strongest relationship with "Consumer perceived value," while "Advertising" (B - 0.747) and "Public relations" (B - 0.690) have the strongest influence. Nevertheless, the coordinated use of a package of marketing communication tools provides greater benefits (stronger and more persuasive communication) in shaping the consumer perceived value than the use of individual communication tools. As a result, it is recommended that organizations focus first on their user, finding out the relevant and desirable values for the current period, which are then communicated using a package of coordinated and complementary marketing communication tools.

This study is to the authors' knowledge the first to offer a vision for value creation for the consumer through marketing communications. The research may be relevant to marketers to gain more loyal customers and to thus increase the competitiveness of their organization through communication tools.

The study is limited, as it was conducted by analyzing one retail chain sector in one country. There is a need for more in-depth analyses related to increasing consumer loyalty by offering the desired values through marketing communication tools. It would be desirable to repeat the study internationally with various respondent populations in order to be able to compare the obtained results and thus draw broader conclusions. In this way it would also be possible to study the effectiveness of specific measures and to assess benefits which would increase the organization's competitiveness in the market.

\section{References}

1. Abtin, A., \& Pouramiri, M. (2016). The impact of relationship marketing on customer loyalty enhancement (Case study: Kerman Iran insurance company). Marketing and Branding Research, 3 (1), 41-49. https://doi.org/10.33844/mbr.2016.60203

2. Baer, J. (2013). Youtility: Why Smart Marketing Is About Help Not Hype. Penguin group. New York. USA. 
3. Baker, S. (2010). New Consumer Marketing: managing a living demand system. 1st Edition. England: Wiley \& Sons.

4. Blakeman, R. (2018). Integrated Marketing Communication: creative strategy from idea to implementation. Rowman \& Littlefield Publishers; Third edition.

5. Candan, B., Unal, S., \& Ercis, A. (2013). Analysing the relationship between consumption values and brand loyalty of young people: A study on personal care products. European Journal of Research on Education, Special Issue: Human Resource Management, 29-46.

6. Dubois, P. L., Flores, L., Jolibert, A., \& Muhlacher, H. (2012). Marketing management: A valuecreation process. 2nd. Edition. Macmillan International Higher Education.

7. El-Adly, M. I., \& Eid, R. (2016). An empirical study of the relationship between shopping environment, customer perceived value, satisfaction, and loyalty in the UAE malls context. Journal of Retailing and Consumer Services, 31, 217-227. https://doi.org/10.1016/j. jretconser.2016.04.002

8. Gan, C., \& Wang, W. (2017). The influence of perceived value on purchase intention in social commerce context. Internet Research, 27 (4), 772-785. https://doi.org/10.1108/IntR-06-20160164

9. Gatautis, R., Banytė, J., Piligrimiené, Ž., Vitkauskaité, E., \& Taruté, A. (2016). The Impact of Gamification on Consumer Brand Engagement. Transformations in Business \& Economics. 15 (1), 173-191. http://www.transformations.knf.vu.lt/37/article/thei

10. Gronroos, Ch., \& Ravald, A. (2011). Service as business logic: implications for value creation and marketing. Journal of Service Management, 22 (1), 5-22. https://doi. org $/ 10.1108 / 09564231111106893$

11. Hanssens, D. M., \& Pauwels, K. H. (2016). Demonstrating the value of marketing. Journal of Marketing, 80 (6), 173-190. https://doi.org/10.1509/jm.15.0417

12. Hassan, A. (2012). The Value Proposition Concept in Marketing: How Customers Perceive the Value Delivered by Firms - A Study of Customer Perspectives on Supermarkets in Southampton in the United Kingdom. International Journal of Marketing Studies, 4 (3), 68-87. https://doi.org/10.5539/ijms.v4n3p68

13. Hsiao, C. C., Yen, H. J. R., \& Li, E. Y. (2011). Exploring consumer value of multi-channel shopping: a perspective of means-end theory. Internet Research, 22 (3), 318-339. https://doi. org/10.1108/10662241211235671

14. Išoraité, M. (2016). Marketing mix theoretical aspects. International journal of reseacrhgranthaalayah, 4 (6), 25-36. https://doi.org/10.5281/zenodo.56533

15. Itani, O. S., Kassar, A. N., \& CorreiaLoureiro, S. M. (2019). Value get, value give: The relationships among perceived value, relationship quality, customer engagement, and value consciousness. International Journal of Hospitality Management, 80, 78-90. https://doi. org/10.1016/j.ijhm.2019.01.014

16. Keller, K. L. (2013). Strategic Brand Management: Building, Measuring, and Managing Brand Equity. Pearson, Business \& Economics. 
17. Khan, M. T. (2013). Customers Loyalty: Concept \& Definition (A Review). International Journal of Information, Business and Management, 5 (3), 168-191.

18. Kotler, Ph, \& Keller, K. L. (2020). Marketing Management. Melbourne: P. Ed Custom Books.

19. Kumar, P., \& Raju, K. V. (2013). The Role of Advertising in Consumer Decision Making. Journal of Business and Management, 14 (4), 37-45. https://doi.org/10.9790/487X-1443745

20. Kumar, V., \& Reinartz, W. (2016). Creating Enduring Customer Value. Journal of Marketing: $A M A / M S, 80$ (6), 36-68, https://doi.org/10.1509/jm.15.0414

21. Lindgreen, A., Hingley, M. K., Grant, D. B., \& Morgan, R. E. (2012). Value in business and industrial marketing: past, present, and future. Industrial Marketing Management, 41 (1), 207-214. https://doi.org/10.1016/j.indmarman.2011.11.025

22. Malik, M. E., Ghafoor, M. M., Iqbal, H. K., Ali, Q., Hunbal, H., Noman, M., \& Ahmad, B. (2013). Impact of Brand Image and Advertisement on Consumer Buying Behavior. World Applied Sciences Journal, 23 (1), 117-122. https://doi.org/10.5829/idosi.wasj.2013.23.01.824

23. Marinov, M. A., \& Marinova, S. T. (2019). Value in Marketing: What Is It and Why Does It Matter? In M. Marinov (Ed.), Value in Marketing: Retrospective and Perspective Stance, 2. 1-8. Routledge. Routledge Frontiers in the Development of International Business, Management and Marketiting, 2. https://doi.org/10.4324/9780429264337-1

24. Martelo Landroguez, S., Barroso Castro, C., \& Cepeda-Carrión, G. (2013). Developing an integrated vision of customer value. Journal of Services Marketing, 27 (3), 234-244. https://doi. org $/ 10.1108 / 08876041311330726$

25. Nezakati, H., Yen, C. P., \& Akhoundi, M. (2013). Antecedents Impact on Brand Loyalty in Cosmetics Industry. Journal of Applied Sciences, 13 (1), 126-132. https://doi.org/10.3923/ jas.2013.126.132

26. Ngo, L. V., \& O'Cass, A. (2010). Value creation architecture and engineering: a business model encompassing the firm-customer dyad. European Business Review, 22 (5), 496-514. https://doi. org/10.1108/09555341011068912

27. Pavlovaite, U., \& Griesiene, I. (2019). Development of an Art Platform in Terms of Relationship Marketing: a Biennial Case. Transformations in Business \& Economics. 18 (2), 259-278.

28. Piercy, N. F. (2016). Market-Led Strategic Change. 5th Edition. London. Routledge.

29. Prahalad, C. K., \& Ramaswamy, V. (2004). Co-creating unique value with customers. Strategy and Leadership, 32 (3), 4-9. https://doi.org/10.1108/10878570410699249

30. Pynnonen, M., Ritala, P., \& Hallikas, J. (2011). The new meaning of customer value: a systemic perspective. Journal of Business Strategy, 32 (1), 51-57, https://doi. org $/ 10.1108 / 02756661111100328$

31. Sánchez-Gutiérrez, J., Cabanelas, P., Lampón, J. F., \& González-Alvarado, T. E. (2019). The impact on competitiveness of customer value creation through relationship capabilities and marketing innovation. Journal of Business \& Industrial Marketing. 34 (3), 618-627. https://doi. org/10.1108/JBIM-03-2017-0081 
32. Shamout M. D. (2016). The Impact of Promotional Tools on Consumer Buying Behavior in Retail Market. International Journal of Business and Social Science, 7 (1).

33. Shanker, A. (2012). A Customer Value Creation Framework for Businesses That Generate Revenue with Open Source Software. Technology Innovation Management Review, 18-22. https:// doi.org/10.22215/TIMREVIEW/534

34. Simova, J. (2009). Conceptual models of customer value: Implications for clothing retailing. E\&M Economics and Management. 2009 (1), 88-97.

35. Singh, P. K., \& Pattanayak, J. K. (2014). The Impact of Brand Loyalty on Consumers' Sportswear Brand Purchase. IUP Journal of Brand Management, 11 (4), 40-52.

36. Smith, J. B., \& Colgate, M. (2014). Customer Value Creation: A Practical Framework. Journal of Marketing Theory and Practice, 15 (1), 7-23. https://doi.org/10.2753/MTP1069-6679150101

37. Solomon, M. R., Marchal, G. W., \& Stuart, E. W. (2017). Marketing: Real People, Real Choices. 9th. Edition. Pearson Education Limited.

38. Strydom, E., Petzer, D. J., \& De Meyer, C. F. (2015). A Multidimensional Customer Value Model for The High Fashion Retail Industry. The Retail and Marketing Review, 11 (2), 111-131. http://hdl.handle.net/2263/59156

39. Wagner, J., \& Benoit, S. (2015). Creating value in retail buyer-vendor relationships: A servicecentered model. Industrial Marketing Management. 44, 166-179. https://doi.org/10.1016/j. indmarman.2014.10.013

40. Wu, Y., \& Li, E. Y. (2017). Marketing mix, customer value, and customer loyalty in social commerce. A stimulus-organism-response perspective. Internet Research, 28 (1), 74-104. https:// doi.org/10.1108/IntR-08-2016-0250

41. Yang, D. J., \& Lee, C. W. (2016). In-store promotional mix and the effects on female consumer buying decisionsin relation to cosmetic products. International Journal of Management, Economics and Social Sciences (IJMESS), 5 (2), 35-56. https://doi.org/hdl:10419/144774

42. Yoong, L., Lian, S., \& Subramaniam, M. (2017). Relationship Value and Relationship Quality: An Exploration of Its Antecedents on Customer Loyalty. Asian Social Sience, 13 (12), 51-62. https://doi.org/10.5539/ass.v13n12p51

43. Zhang, M., Gou, L., Hu, M., \& Liu, W. (2016). Influence of customer engagement with company social networks on stickiness: Mediating effect of customer value creation. International Journal of Information Management. 37 (3), 229-240. https://doi.org/10.1016/j. ijinfomgt.2016.04.010 


\section{Contact information}

Viktorija Kovanoviene

Vilnius University

Kaunas Faculty

Institute of Social Sciences and Applied Informatics

Muitines 8, LT-44280, Kaunas

Lithuania

E-mail:v.kovanoviene@gmail.com

ORCID 0000-0002-6008-1696

Dr. Giedrius Romeika

Vilnius University

Kaunas Faculty

Institute of Social Sciences and Applied Informatics

Muitines 8, LT-44280 Kaunas

Lithuania

E-mail: giedrius.romeika@knf.vu.lt

ORCID 0000-0001-9852-7107

Wjatscheslav Baumung

Reutlingen University

Department of Business Informatics

Alteburgstraße 150, 72762 Reutlingen

Germany

E-mail:wjatscheslav.baumung@reutlingen-university.de

ORCID 0000-0003-1374-3412 